248. 冠循環に関する実験的研究

（金沢大 第二内科）太田 追分 久憲・神川 上坂 敏弘・田中 竹田亮祐

正常麻酔犬にて左冠動脈に Jadkins カテーテルを，冠 静脈洞に二腔カテーテルを留置し，指示薬稀积法により 平均冠循環時間之冠静脈洞血流量を测定し，循烃木冠血液 容量を算出した。この方法を用いてニトログリセリン， ジピリダモール，プロスタグランディン $\mathrm{E}_{1}$ および $\mathrm{I}_{2}$ の 冠循環に及湆す影響を観察した。本法により求められた 冠血液容量は冠拡張の直接の指標として非開䒽的, 経時 的に観察出来る利点を有するものと思われた。

249. 冠血流の心臟内配分と心機能

(岡山大 第二外科) 妹尾 嘉昌・青景 和英 中山賴和・水取 悦生・水野裕 芝一成・寺本滋 （高松病院 外科）笠井 敏雄

脱血低血圧，Endotoxin 冠動脈注入による低血圧，体 外循環負荷を行ない，冠動脈血の心臓内配分を検討し， 心機能との関連を追求した。脱血群，体外循環群では右 室，右房へ有意に增加し，左室が減少した。翉能注変 化しなかった．ET 群では心筋内血流配分は対照時々变 化はなかったが，心機能，冠血流量の減少は他群より有 意に減少した，負荷心の心機能の变化は冠血流の冠内血 流配分の異常にもとずくものではないと推察された。

\section{0. 大動脈起始部の冠循環の調節に関する研究}

(黢河台日大病院 循環器科) 黒田一明 暒原 長雄・住々木 喬・越野 正行 高橋玄太郎・久保田 稔・古堅 宗昭 山村 昭夫・圾井克一郎・植田 博紀 上松瀬 悠・杉浦 文夫・福井陽 波多野道信

我々は過去14年間に亘り頸動脈洞反射, 頸動脈洞電気 刺激, 頸動脈化学受容体並びに大動脈体反射につき報告 してきた，今回は，体循環と冠循環を分離したランダン ドルフ犬変法を用い定量灌流により大動脈起始部の血流 を維持し，星状神経節刺激により大動脈起始部压の变化 が冠血流量の調節に関与する事を，ぬた $\alpha$ 乱よび $\beta$ 遮 断剂により大動脈起始部圧の低下とともに冠血流量の変 化する事を認めた。

251. ショック時の心筋内血流分布と心機能

(岡山大 第二外科) 青景 和英・中山 頼和 水取 悦生・芝一成・水野裕 川上 俊爾・妹星 嘉昌・寺本滋

平均動脈生 $50 \mathrm{mmHg}$ の shock を2 群—( ( 群) $\mathrm{E}$, coli Endotoxin 济よる心原性 shock, (II 群) 脱血性 shock 一一支作製し，心筋内血流分有，心機能より，その病態 の差違を検討し，薬剤(Dobutamine, carnigen)の効果を
みた。I群はII 群に比し心収縮力がより低下し， total CBF の減少もより著明であった。 心筋内血流分布の不 均衡は認めなかった。 II 群では右室への血流分布率が増 加し，左室内/外比では1.0以下を示し，心筋内血流分布 の不均衡が認められた。

(14:20-14:50) 座長 阿部 博幸(順大)

252. 不整脈における冠血行動態に関する実験的研究 - - 期外収縮と冠動脈拍動流——

（愛媛大 第二内科）城 忠文・今村 陽一 越智 隆明・矢野 和夫・稲田 貫 国府 達郎

（同中央検查部）茎田 仝志·青野 賢治 心房性期外収縮 (APC)，心室性期外収縮 (VPC) 飞叔故 る期外収縮連結期 (CT) との関連飞乱いて期外収縮前後 の冠動脈拍動流 (SCF) 飞ついて検討した。期外収縮直前 心拍で CT の短縮と共に直線的に減少した。これは搪張 期の短縮によるものであった，次の心拍で増加を示した が APC では先行の減少分を代償するものでなかった。 VPC で代償性休止期により著明增加を見た。続く心拍 では駆出期血流量ほ増加したが全体轠は著变なかった。

\section{3. 冠血管遮断時間の反応性充血に及ぼす影響} 一その血流栐式について一

（群馬大 第二内科）佐々木豊志・前原 和平 中村 雄一・高瀬 真一・渡部 正敏 村田 和彦

反応性充血に影響を与兄る因子を解明する為犬の血流 を2 40秒遮断した時の反応性充血について検討した. \% repayment は冠遮断 8 秒まで増加し一定となる. 収 縮期流量は昖張期流量に比し早期に増加，減少した。 propranolol 投与後もこの現象は变化しなかったが，\% repayment ほ減少し，収縮期流量は増加した。短時間 の冠遮断でも反応性充血があり，収縮期流量が早期に減 少する事は，代謝産物以外の因子関与を示唆する。

\section{4. 冠動脈狭窄時の vascular waterfall 現象の病態 生理学的意義について \\ 一特に“spontaneous oscillation” の検討一 \\ (川崎医大 ME- システム循環器) 梶谷 文彦 伯耆 德武・今村 正敏}

冠循環系の “vascular waterfall”現象, 特に spontaneous oscillation の臨床病態学的意義を把握する目的 で，生体内での vascular waterfall 現象の実現条件和よ び spontaneous oscillation 影響を与去る要因をin vivo, in vitro.で検討した。 その結果, (1)生体内動脈系に拉 いても"vascular waterfall 現象が生じ，それは末梢血 管系の状態や血管の引っぽり，tetherに大きく影響され ること, (2)vascular waterfall 時に見られる spontaneos oscillation による流れエネルギーの Loss が大きいこと などが示された。 